\title{
Synthesis, Assessment of Biological Activity and Toxicity for $\mathrm{N}-(\beta$-D-Glycopyranosyl)- Thiosemicarbazides
}

\author{
Baktygul Ernazarova1, Asylkan Dzhumanazarova², Aida Bakirova1, \\ Zhypargul Abdullaeva ${ }^{3 *}$ (D) Gulsara Zhusupbaeva4, \\ Zarylkan Asylbek Kyzy5, Momun Arzybaev ${ }^{6}$
}

\begin{abstract}
${ }^{1}$ Department of Medical-Biological Disciplines, Zhalal-Abad State University, Zhalal-Abad, Kyrgyzstan
${ }^{2}$ Institute of Chemistry and Phytotechnology, National Academy of Sciences, Bishkek, Kyrgyzstan

${ }^{3}$ Science and Research Department, Osh State University, Jolon Mamytov Campus, Osh, Kyrgyzstan

${ }^{4}$ Zhalal-Abad Scientific Center, South Department Academy of Sciences, Zhalal-Abad, Kyrgyzstan

${ }^{5}$ Department of Pharmacy and Medical-Biological Disciplines, Zhalal-Abad State University, Zhalal-Abad, Kyrgyzstan

${ }^{6}$ Department of Biotechnology, Kyrgyz National Agrarian University Named after K.I. Skryabin, Bishkek, Kyrgyzstan

Email: *jypar.science@oshsu.kg
\end{abstract}

How to cite this paper: Ernazarova, B., Dzhumanazarova, A., Bakirova, A., Abdullaeva, Z., Zhusupbaeva, G., Kyzy, Z.A. and Arzybaev, M. (2020) Synthesis, Assessment of Biological Activity and Toxicity for N( $\beta$-D-Glycopyranosyl)-Thiosemicarbazides. International Journal of Organic Chemistry, 10, 159-169.

https://doi.org/10.4236/ijoc.2020.104012

Received: October 29, 2020

Accepted: December 4, 2020

Published: December 7, 2020

Copyright $\odot 2020$ by author(s) and Scientific Research Publishing Inc. This work is licensed under the Creative Commons Attribution International License (CC BY 4.0).

http://creativecommons.org/licenses/by/4.0/

\begin{abstract}
In the modern science, priority is given for the search of biological active compounds with specific properties. As a result of experimental data, it was found that in the reaction between $\mathrm{N}$-( $\beta$-D-glycopyranosyl)-semicarbazide and the Lawesson reagent (2,4-bis(p-methoxyphenyl)-1,3-dithiadiphosphetane 2,4-disulfide) at the ratio 1:1 in pyridine when boiling under reflux in a water bath for 20 - 35 minutes, a new synthetic compound N-( $\beta$-D-glycopyranosyl)thiosemicarbazide is formed. The individuality and structure of the target products were confirmed by ${ }^{13} \mathrm{C}$ NMR spectroscopy, $1 \mathrm{H}$ NMR spectroscopy, IR spectroscopy, and elemental analysis. For the synthesized new compounds of $\mathrm{N}$-( $\beta$-D-glycopyranosyl)-thiosemicarbazides, the probability of pharmacological and toxic effects were predicted by the computer method in silico. From the synthesized compounds $\mathrm{N}$-( $\beta$-D-galactopyranosyl)-thiosemicarbazide, the probability of antibacterial (antibacterial) activity is predicted ( $\mathrm{Pa} / \mathrm{Pi} 0.544 / 0.013$ ). The antibacterial activity of the compound (4) was confirmed in a test for salmonella infection of lambs, salmonellosis of calves, and colipathogenic $E$. coli serotypes. An experimental study by the in vitro method made it possible to conclude that the new synthetic compound $\mathrm{N}$-( $\beta$-D-galactopyranosyl)thiosemicarbazide in the studied concentrations has a pronounced bactericidal and bacteriostatic effect. The synthetic new compound $\mathrm{N}-(\beta$-D-glycopyranosyl)-thiosemicarbazide is a promising compound for further study.
\end{abstract}




\section{Keywords}

Assessment of Biological Activity, Synthesis of Carbohydrate Derivatives of Urea, Toxicity, Antibacterial, Antiviral Activity

\section{Introduction}

In recent years, thiosemicarbazides have attracted more and more attention from researchers, based on which it is possible to form a variety of derivatives that are used in medicine as drugs with antimicrobial, anti-tuberculosis, antitumor, antifungal effects [1] [2].

It is widely known that carbohydrates can play a transport role in the body. Therefore, the search for ways to obtain new carbohydrate-containing derivatives of thiosemicarbazides is of fundamental importance for modern pharmacology. For this purpose, we carried out prospecting work on the selection of reaction conditions for obtaining carbohydrate-containing derivatives of thiosemicarbazides.

It is known that the Lawesson reagent was successfully used in the thionation of the carbonyl group of many classes of organic compounds [3] [4] [5]. However, the reaction of thionization of carbohydrate-containing semicarbazides using the Lawesson reagent to obtain thiosemicarbazides is still not sufficiently studied.

Our study aims to develop a new method for the synthesis of carbohydrate-containing derivatives of thiosemicarbazides based on the reactions of $\mathrm{N}$-glycosylated semicarbazides when interacting with the Lawesson reagent and to study their biological properties. In particular, $\mathrm{N}$ - $(\beta$-D-xylopyranosyl)thiosemicarbazide and $\mathrm{N}$-( $\beta$-D-galactopyranosyl)-thiosemicarbazide have been studied. To select from them the most promising compound exhibiting antibacterial properties, we preliminarily carried out computer analysis through the PASS program [6]; then the selected compound was tested in vivo and in vitro to confirm the predicted activities.

\section{Materials and Methods}

\subsection{Synthesis of N-( $\beta$-D-Xylopyranosyl)-Thiosemicarbazide}

A flask was charged with $0.05 \mathrm{~g}(0.24 \mathrm{mmol})$ of $\mathrm{N}$ - $(\beta$-D-xylopyranosyl $)$-semicarbazide, $3 \mathrm{ml}$ abs. pyridine and $0.1 \mathrm{~g}(0.24 \mathrm{mmol})$ (Lawesson reagent) LR. The reaction mixture was boiled under reflux with a calcium chloride tube for 20 minutes. The solution was evaporated under vacuum at $70^{\circ} \mathrm{C}-75^{\circ} \mathrm{C}$ to dryness. The residue was recrystallized from alcohol. The precipitated crystals were filtered off and dried in air. Yield: $0.0178 \mathrm{~g},(35.60 \%), \mathrm{T}_{\text {melt }}=217^{\circ} \mathrm{C}-219^{\circ} \mathrm{C}, \mathrm{Rf}=$ $0.8 \mathrm{C}_{6} \mathrm{H}_{13} \mathrm{~N}_{3} \mathrm{O}_{4} \mathrm{~S}$ 223.25 Calculated\%: C-32.28; $\mathrm{H}$ 5.86; N 18.82; S-14.36. Found \%: C-32.40; H 6.10; N 18.97; S-14.47. IR spectrum (KBr, $\left.v, \mathrm{~cm}^{-1}\right): 1108$ (-CO-), 901 ( $\beta$-form), 1028 (pyran.), $1377(\mathrm{C}=\mathrm{S}), 3251(\mathrm{NH}), 3377\left(\mathrm{NH}_{2}\right), 3000-3400(\mathrm{OH})$. 
${ }^{1} \mathrm{H}$ NMR spectrum millionths proportion $(\delta$, m.p.): 3.88 qt. 3.41 triplet 3.49 $3.76 \mathrm{~m}(\mathrm{CH}, 6 \mathrm{H}), 2.0$ broad singlet $(3 \mathrm{OH}) 4.81 \mathrm{~d}(1 \mathrm{H}, \mathrm{NH}), 2$ br.s $(\mathrm{NH} 2 ; \mathrm{NH}$, 3H). ${ }^{13} \mathrm{C}$ NMR spectrum ( $\delta$, m.p.): 90.5 (C1), 73.9 (C2) 77.0 (C3) 70.1 (C4) 67.8 (C5) $183.6(\mathrm{C}=\mathrm{S})$.

\subsection{Synthesis of N-( $\beta$-D-Galactopyranosyl)-Thiosemicarbazide}

A flask was charged with $0.05 \mathrm{~g}(0.24 \mathrm{mmol})$ of $\mathrm{N}$-( $\beta$-D-galactopyranosyl)semicarbazide, $3 \mathrm{ml}$ abs. pyridine and $0.09 \mathrm{~g}(0.22 \mathrm{mmol})$ LR. The reaction mixture boiled under reflux with a calcium chloride tube for $35 \mathrm{~min}$. The solution evaporated under vacuum at a temperature of $75^{\circ} \mathrm{C}-80^{\circ} \mathrm{C}$ to dryness. The residue recrystallized from alcohol. The precipitated crystals filtered off and dried in air. Yield: $0.023 \mathrm{~g},(46.00 \%), \mathrm{mp}=210-2110 \mathrm{C}, \mathrm{Rf}=0.9 . \mathrm{C}_{7} \mathrm{H}_{15} \mathrm{~N}_{3} \mathrm{O}_{5} \mathrm{~S} 253.27$ Calculated \%: C-33.19; H 5.96; N 16.59; S-12.65. Found \%: C-33.36; H 6.28; N 16.75; S-12.98. IR spectrum ( $\left.\mathrm{KBr}, v, \mathrm{~cm}^{-1}\right): 1138$ (-CO-), 908 ( $\beta$-form), 1000 (pyran.), 1332, $1439(\mathrm{C}=\mathrm{S}), 3251(\mathrm{NH}), 3369(\mathrm{NH} 2), 3178-3369(\mathrm{OH}) .1 \mathrm{H}$ NMR spectrum ( $\delta$, m.p.): 3.79 m, 3, 4 tripl. 3.48 - $3.76 \mathrm{~m}(\mathrm{CH}, 7 \mathrm{H}), 2.1$ br.s $(\mathrm{OH}$, $4 \mathrm{H}), 4.83 \mathrm{~d}(1 \mathrm{H}, \mathrm{NH}), 2$ br.s $(\mathrm{NH} 2 ; \mathrm{NH}, 3 \mathrm{H}) .{ }^{13} \mathrm{C}$ NMR spectrum $(\delta$, m.p.): 88.3 (C1), 74.2 (C2), 74.8 (C3), 71.2 (C4), 79.1 (C5), 62.0 (C6), 183.5 (C=S).

\section{Results and Discussions}

The syntheses of $\mathrm{N}-(\beta$-D-xylopyranosyl)-thiosemicarbazide and $\mathrm{N}-(\beta$-D-galactopyranosyl)-thiosemicarbazides (Figure 1 ) were performed according to the scheme shown in Figure 2, where Ry means xylopyranosyl, 2b means galactopyranosyl.

The reaction proceeds rather quickly, so that we failed to detect the intermediate formation of the corresponding products. Most likely, this is due to the decomposition of the Lawesson reagent (1) into dithiometaphosphonate (1a), which has a resonance structure. The interaction of dithiometaphosphonate with glycosylsemicarbazides leads to the formation of intermediate cyclic thioketals $(1 \mathrm{~b}, 1 \mathrm{c})$, the subsequent decomposition of which leads to the formation of final products $(3,4)$.

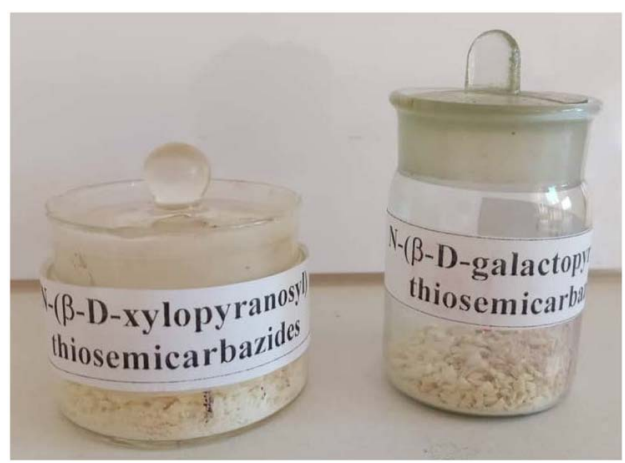

Figure 1. Synthesized tiosemicarbazide derivatives $\mathrm{N}$-( $\beta$-D-xylopyranosyl)-thiosemicarbazide and $\mathrm{N}$-( $\beta$-D-galacto-pyranosyl)-thiosemicarbazides. 


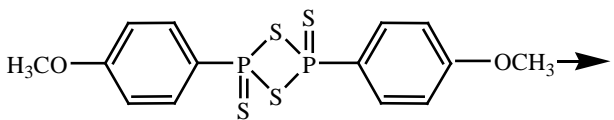

(1)
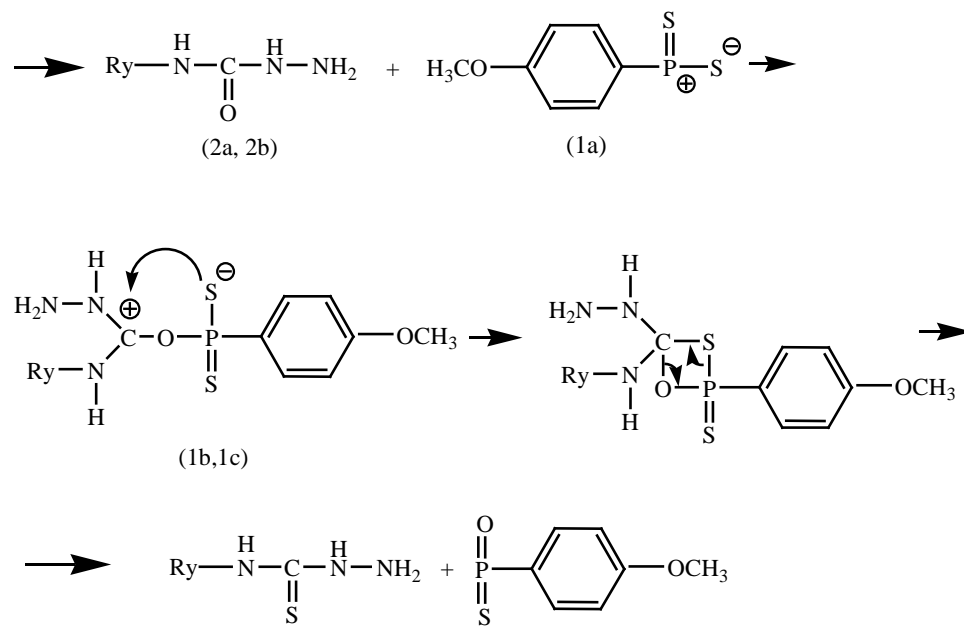

$(3,4)$

Figure 2. The reaction for the preparation of $\mathrm{N}-(\beta$-D-glycopyranosyl)-thiosemicarbazides.

The individuality and structure of the target products were confirmed by ${ }^{13} \mathrm{C}$ NMR, ${ }^{1} \mathrm{H}$ NMR, IR spectroscopy, and elemental analysis. In the ${ }^{13} \mathrm{C} N M R,{ }^{1} \mathrm{H}$ NMR spectra of the synthesized compounds, the signals of all the corresponding nuclei included in the obtained compounds are observed. ${ }^{13} \mathrm{C}$ NMR spectra were recorded on a Bruker AM-300, $\mathrm{SF}=75.47 \mathrm{MHz}$ instruments with an operating frequency of $126 \mathrm{MHz}$ at a temperature of $2950 \mathrm{~K}$, where TMS was used as an internal standard. $\mathrm{H}^{1}$ NMR spectra were recorded on a Bruker AM-300, $\mathrm{SF}=$ $300.13 \mathrm{MHz}$ instruments with an operating frequency of $500 \mathrm{MHz}$ at a temperature of $2930 \mathrm{~K}$, where TMS was used as an internal standard. The spectra were recorded in deuterated solvents DMSO $\mathrm{d}_{6}$. IR spectra were recorded on an IKS-29 instrument in the range of $500-4000 \mathrm{~cm}^{-1}$.

The melting points of the synthesized compounds were measured on a Boetuis microheating table. The elemental analysis of the obtained compounds was determined on a VM-20 instrument. The control throughout the reaction and the purity of the synthesized compounds was carried out using TLC on Silufol UV-254 plates.

To prognose the biological activity of the newly synthesized compounds, we used the PASS computer program developed by the Institute of Biomedical Chemistry named after V.N. Orekhovich RAMS.

The use of the PASS program makes it possible to select those compounds that are most likely to possess the required types of biological activity among the extensive set of analyzed compounds. Along with this, the program provides information on unwanted side effects. This is important since when choosing promising compounds, not only main but also side pharmacological effects are taken into account. 
In vitro and vivo experiments of the synthesized compounds were carried out at the Department of Biotechnology and Chemistry of the Kyrgyz National Agrarian University named after K.I. Skryabin and in the bacteriology department of the Kyrgyz Republican Diagnostic Center.

\subsection{In Vitro Studies}

Experiments on studying the antibacterial activity of $\mathrm{N}-(\beta$-D-galactopyranosyl)thiosemicarbazide were carried out by the in Vitro method using standard bacteriological methods [7]. For this, by serial dilutions with distilled water (1:10; $1: 20 ; 1: 40 \ldots 1: 2650)$, various concentrations of the substance were prepared. The bactericidal effect was studied by inoculation on agar-agar in Petri dishes of salmonella infection of lambs (Salmonella typhimurium, 04), salmonellosis of calves (Salmonella dublin, 09), and colipathogenic serotypes of Escherichia coli (Escherichiacoli 055, 026), adding $0.1 \mathrm{ml}$ of each dilution of the substance.

The results were taken into account after daily cultivation in a thermostat at $t$ $=37^{\circ} \mathrm{C}$, by measuring the diameter of the zones (in $\mathrm{mm}$ ), and by the absence of microorganism growth at the site of application of the compound. Distilled water (i.e. solvent) served as a control.

\subsection{Study of Acute Toxicity in Vivo}

When searching for the most promising compounds for practical use, it is necessary to study the toxicology of newly synthesized compounds and the first necessary condition for the suitability of a compound is to determine the parameters of its acute toxicity. These indicators are necessary to establish the degree of hazard of a chemical, as well as for further research, where knowledge of the degree of acute toxicity is required.

The study of acute toxicity aims to determine the tolerable, toxic, and lethal doses of a pharmacological substance and the cause of death of animals.

Acute toxicity of pharmacological substances is determined by the following parameters: $\mathrm{LD}_{0}$ is the maximum tolerated dose, $\mathrm{LD}_{50}$ is the average lethal dose, $\mathrm{LD}_{100}$ is the minimum lethal dose. $\mathrm{LD}_{16}$ and $\mathrm{LD}_{84}$ are also determined to establish the confidence limits of $\mathrm{LD}_{50}$ is the average lethal dose. There are many classifications of chemicals for assessing acute toxicity [7]. To assess the toxicity of antiparasitic drugs, the classification according to [8] [9] is more suitable. Based on the foregoing, we studied the acute toxicity parameters of a new synthetic compound $\mathrm{N}-(\beta$-D-galactopyranosyl)-thiosemicarbazide.

The experiments were carried out on 36 clinically healthy white mice of both sexes with a live weight of $18-22 \mathrm{~g}$. The substance was administered to the animals orally in the form of a $10 \%$ solution using a syringe equipped with a special metal probe, in various doses. Control animals received an appropriate volume of sodium chloride saline solution.

During the experiment, the animals were not limited to feeding and watering. The experiments lasted 12 days, during which the general condition, the nature, 
and degree of chemical toxicosis, the time of death of the experimental and control mice were observed. The corpses of the dead experimental animals were subjected to visual, as well as postmortem autopsy to establish the degree and nature of organ damage and the causes of death. Statistical processing of digital materials was carried out by the method [10], modified [11], using ordinary graph paper [12].

The progress of the reactions and the individuality of the obtained compounds were monitored using the methods of thin-layer chromatography in systems:chloroform: ethanol:methyl ethyl ketone (1:2:1). The synthesized compounds are crystalline substances with chemical stability. They are stored without decomposition at room temperature and are stable under TLC conditions.

In the IR spectrum of compound (4), the most informative for identification is the region at $1332,1439 \mathrm{~cm}^{-1}$, which belongs to the stretching vibrations of the $\mathrm{C}=\mathrm{S}$ group. The absorption bands in the $1530 \mathrm{~cm}^{-1}$ region indicate the bending vibrations of the $\mathrm{N}-\mathrm{H}$ group, and in the $1138 \mathrm{~cm}^{-1}$ and $1000 \mathrm{~cm}^{-1}$ regions the presence of carbohydrate components. The absorption band at $908 \mathrm{~cm}^{-1}$ refers to the $\beta$-position of the carbohydrate ring. A wideband in the region of $3178-3369$ $\mathrm{cm}^{-1}$ corresponds to the stretching vibrations of $\mathrm{OH}-$ and $\mathrm{N}-\mathrm{H}$ groups.

The low-field part of the PMR spectrum of compound 4 contains signals that appear as a multiplet centered at $3.48 \mathrm{~m}$.p. to $3.76 \mathrm{~m} . \mathrm{p}$. respectively, belonging to the fifth axial and fifth equatorial hydrogen atoms of the carbon-water ring. The equatorial hydrogen atom at C-2 appears as a doublet with a chemical shift at 3.79 m.p. A signal in the form of a broadened singlet belonging to the protons of the methyl group $\mathrm{CH}_{3}$ was observed at 2.1 m.p. The $\mathrm{NH}$ group is observed as a doublet at 4.83 m.p.

\subsection{Prognosis of Biological Activities of Synthesized Compounds by PASS Program}

Present an ordered list of the types of possible activities, indicating the probability of the presence of activity $(P a)$ and the probability of inactivity $(P \dot{I})$. From the data obtained, the types of activities were selected for which the Pa indicator is maximum, and the $P i$ indicator is minimum. In computer forecasting, the values of the probability of activity manifestation $P a \geq 0.5$ were taken into account. Table 1 shows the results of predicting 14 types of biological activity, as well as side toxic effects in $\mathrm{N}$-( $\beta$-D-xylopyranosyl)-thiosemicarbazide and $\mathrm{N}$-( $\beta$-D-galactopyranosyl)thiosemicarbazide in the form of values of the probability of the presence of activity $(P a)$ and the probability of inactivity $(P I)$.

Since we were interested in the antibacterial activity of the studied compounds, we focused on this activity. As can be seen (Table 1), of the two compounds 3 and $4, \mathrm{~N}$-( $\beta$-D-galactopyranosyl)-thiosemicarbazide is predicted as a more promising substance with a high probability of antibacterial activity $(\mathrm{Pa} / \mathrm{Pi}$ $0.544 / 0.004$ Antibacterial). The same table shows the values of possible toxic effects with a probability $P a>0.5$ for compounds 3,4 . 
Table 1. Results of predicting pharmacological and toxic effects glycosylthiosemicarbazides using the PASS program.

\begin{tabular}{|c|c|c|c|}
\hline \multicolumn{2}{|c|}{ No. Compound name } & $\begin{array}{l}\text { Prognosis of pharmacological effects } \\
P a / P i \text { type of activity }\end{array}$ & $\begin{array}{l}\text { Prognosis of toxic effects } \\
P a / P i \text { type of toxicity }\end{array}$ \\
\hline 3 & $\begin{array}{l}\mathrm{N}-(\beta \text {-D-xylopyranozyl)- } \\
\text { thiosemicarbazide }\end{array}$ & $\begin{array}{l}6 \text { of } 464 \text { Possible Pharmacological Effects at } P a>0.500 \\
0.6540 .007 \text { Antimycobacterial } \\
0.6370 .037 \text { Antineoplastic } \\
0.5930 .005 \text { Antidiabetic symptomatic } \\
0.5760 .004 \text { Antineoplastic (small cell lung cancer) } \\
0.5480 .005 \text { Restenosis treatment } \\
0.5230 .010 \text { Antituberculosic }\end{array}$ & $\begin{array}{l}9 \text { of } 321 \text { Possible Toxic and Adverse Effects at } P a>0.500 \\
0.7470 .010 \text { Hyperuricemia } \\
0.6800 .046 \text { Neuritis } \\
0.6640 .052 \text { Renal insufficiency } \\
0.6430 .031 \text { Acidosis, metabolic } \\
0.6280 .042 \text { Acidosis } \\
0.6400 .067 \text { Anemia, hemolytic } \\
0.6400 .067 \text { Hyperactivity } \\
0.5740 .111 \text { Dysesthesia } \\
0.5120 .089 \text { Optic neuritis }\end{array}$ \\
\hline 4 & $\begin{array}{l}\mathrm{N}-(\beta \text {-D-galactopiranozyl)- } \\
\text { thiosemicarbazide }\end{array}$ & $\begin{array}{l}14 \text { of } 464 \text { Possible Pharmacological Effects at } P a>0.50 \\
0.7990 .004 \text { Antimycobacterial } \\
0.7180 .004 \text { Antituberculosic } \\
0.7000 .004 \text { Restenosis treatment } \\
0.6790 .007 \text { Antiviral (Influenza) } \\
0.6850 .029 \text { Antineoplastic } \\
0.6280 .013 \text { Antiviral (Pox-virus) } \\
0.5860 .005 \text { Antidiabetic symptomatic } \\
0.5430 .005 \text { Antiviral } \\
0.5640 .028 \text { Immunostimulant } \\
0.5490 .014 \text { DNA synthesis inhibitor } \\
0.5390 .005 \text { Antioxidant } \\
0.5440 .013 \text { Antibacterial } \\
0.5110 .024 \text { Cytostatic } \\
0.5080 .022 \text { Antidiabetic }\end{array}$ & $\begin{array}{l}023 \text { of } 321 \text { Possible Toxic and Adverse Effects at } P a>0.500 \\
0.8180 .005 \text { Hyperuricemia } \\
0.6890 .039 \text { Diarrhea } \\
0.6820 .047 \text { Renal insufficiency } \\
0.6820 .049 \text { Myocardial ischemia } \\
0.6520 .048 \text { Hypoxia } \\
0.6280 .035 \text { Optic neuritis } \\
0.6200 .042 \text { Psychoses } \\
0.6050 .027 \text { Peripheral neuropathy } \\
0.5990 .046 \text { Optic neuropathy } \\
0.5960 .080 \text { Hyperactivity } \\
0.5490 .051 \text { Ototoxicity }\end{array}$ \\
\hline
\end{tabular}

From Table 1 it can be seen that no toxic effect is predicted for compounds 3 , 4. Therefore, for compound 4, an experimental assessment of the bacterial and bacteriostatic activity was carried out, and then the toxicity of this compound was also experimentally evaluated.

\subsection{Results of in Vitro Experiments}

The results of in vitro experiments carried out on a solid nutrient medium show (Table 2$)$ that $\mathrm{N}$-( $\beta$-D-galactopyranosyl)-thiosemicarbazide exhibited bactericidal activity against the selected microbial cultures, although there was no pronounced species specificity in its action.

The bacteriostatic activity of the substance was studied by diluting it in meat-peptone broth at the same concentrations as in the previous experiment, followed by sowing pure cultures in it. The measurement results are shown in Table 3.

The results of this series of experiments showed (Table 4) that the substance bacteriostatically acts on Esch. coli 055 from a dilution of 1: 380, for other crops from a dilution of 1:640. Thus, the conducted studies show that $\mathrm{N}$-( $\beta$-D-galactopyranosyl)thiosemicarbazide exhibits high antibacterial (bactericidal and bacteriostatic) activity against the causative agents of salmonella infection in lambs, calves, and pathogenic E. coli serotypes. 
Table 2. Bactericidal activity of $\mathrm{N}$-( $\beta$-D-galactopyranosyl)-thiosemicarbazide on solid nutrient medium (agar-agar).

\begin{tabular}{|c|c|c|c|c|c|c|c|c|c|}
\hline \multirow{2}{*}{ Microorganisms } & \multicolumn{9}{|c|}{ Dilution of substance } \\
\hline & $1: 10$ & $1: 20$ & $1: 40$ & $1: 80$ & $1: 160$ & $1: 380$ & $1: 640$ & $1: 1280$ & $1: 2560$ \\
\hline & \multicolumn{9}{|c|}{$\mathrm{N}$-( $\beta$-D-galactopiranozyl)-thiosemicarbazide } \\
\hline Sal. typhimurium 04 & $22^{*}$ & 20 & 18 & 16 & 14 & 7 & 3 & 1 & 0 \\
\hline Sal. dublin 09 & 20 & 19 & 18 & 17 & 13 & 6 & 2 & 1 & 0 \\
\hline Esch. coli 055 & 21 & 20 & 19 & 16 & 13 & 7 & 4 & 2 & 0 \\
\hline Esch. coli 026 & 20 & 19 & 17 & 14 & 12 & 8 & 4 & 2 & 1 \\
\hline \multicolumn{10}{|c|}{ Distilled water } \\
\hline Sal. typhimurium 04 & - & - & - & - & - & - & - & - & - \\
\hline Sal. dublin 09 & - & - & - & - & - & - & - & - & - \\
\hline Esch. coli 055 & - & - & - & - & - & - & - & - & - \\
\hline Esch. coli 026 & - & - & - & - & - & - & - & - & - \\
\hline
\end{tabular}

${ }^{*}$ The numbers show the diameter of the zones of no microorganism growth (in $\mathrm{mm}$ ).

Table 3. Biostatic activity of $\mathrm{N}$-( $\beta$-D-galactopyranosyl)-thiosemicarbazide in the meatpeptone broth.

\begin{tabular}{|c|c|c|c|c|c|c|c|c|c|}
\hline \multirow{2}{*}{ Microorganisms } & \multicolumn{9}{|c|}{ Dilution of substance } \\
\hline & $1: 10$ & $1: 20$ & $1: 40$ & $1: 80$ & $1: 160$ & $1: 380$ & $1: 640$ & $1: 1280$ & $1: 2560$ \\
\hline & \multicolumn{9}{|c|}{$\mathrm{N}$-( $\beta$-D-galactopiranozyl)-thiosemicarbazide } \\
\hline Sal. typhimurium 04 & - & - & - & - & - & - & + & + & + \\
\hline Sal. dublin 09 & - & - & - & - & - & - & + & + & + \\
\hline Esch. coli 055 & - & - & - & - & - & + & + & + & + \\
\hline Esch. coli 026 & - & - & - & - & - & - & + & + & + \\
\hline \multicolumn{10}{|c|}{ Distilled water } \\
\hline Sal. typhimurium 04 & + & + & + & + & + & + & + & + & + \\
\hline Sal. dublin 09 & + & + & + & + & + & + & + & + & + \\
\hline Esch. coli 055 & + & + & + & + & + & + & + & + & + \\
\hline Esch. coli 026 & + & + & + & + & + & + & + & + & + \\
\hline
\end{tabular}

*The numbers show the diameter of the zones of no microorganism growth (in $\mathrm{mm}$ ).

Table 4. Acute toxicity parameters of $\mathrm{N}$-( $\beta$-D-galactopyranosyl)-thiosemicarbazide.

\begin{tabular}{ccccc}
\hline Dosage, $\mathrm{ml} / \mathrm{sp}$. & Mouse sp. quantity & \multicolumn{2}{c}{ Results } & Acute toxicity parameters, $\mathrm{mg} / \mathrm{kg}$ \\
\hline & 6 & Dead & Live & \\
400 & 6 & 0 & 6 & $\mathrm{LD}_{0}=400$ \\
800 & 6 & 2 & 5 & $\mathrm{LD}_{16}=754$ \\
1200 & 6 & 3 & 4 & $\mathrm{LD}_{50}=1134$ \\
1600 & 6 & 4 & 2 & $(957 \pm 1311)$ \\
2000 & 6 & 6 & 0 & $\mathrm{LD}_{84}=1534$ \\
Control & 6 & 0 & 6 & $\mathrm{LD}_{100}=2000$ \\
\hline
\end{tabular}


The results of in vivo toxicity tests showed that the nature and degree of chemical intoxication in white mice were in direct proportion to the doses of $\mathrm{N}$-( $\beta$-D-galactopyranosyl)-thiosemicarbazide received. Signs of poisoning when giving large doses appeared in the very first minutes and were often fatal within 1 - 2 hours after giving. They were mainly expressed in the manifestation of an excited state (anxiety, increased reaction to external stimuli, tachycardia, rapid breathing), from food, from water. Then this state turned to progressive oppression, leading to complete prostration. Breathing is shallow, frequent, intermittent. Rapid palpitations, at times, turn into arrhythmia. The death of animals that received large toxic doses of the compound occurred mainly on the first day of administration of the substance. The surviving animals showed mild diarrhea and poor appetite, which soon completed.

The postmortem autopsy of the dead white mice revealed: the back of the corpses is soiled with liquid feces; the brain is swollen, hyperemic; the mucous membrane of the stomach and intestines is strongly hyperemic, in some places there are areas of extensive hemorrhage and necrosis; the liver is enlarged, dark red, its parenchyma is softened; kidneys of normal size, multiple punctate hemorrhages under the membrane; the heart is flabby, the myocardium is soft, the ventricles contain dark red blood clots, there are punctate hemorrhages on the epicardium and endocardium; the lungs are edematous in dark red color, the blood vessels are dilated.

The results of statistical processing of digital experimental data showed that (Table 4$)$ the maximum tolerated dose $\left(\mathrm{LD}_{50}\right)$ of $\mathrm{N}-(\beta$-D-galactopyranosyl)thiosemicarbazide for white mice was $400 \mathrm{mg} / \mathrm{kg}, \mathrm{LD}_{16}$ was $754 \mathrm{mg} / \mathrm{kg}$, average lethal dose $\mathrm{LD}_{50}$ was $1134(957 \pm 1311) \mathrm{mg} / \mathrm{kg}, \mathrm{LD}_{84}$ was $1534 \mathrm{mg} / \mathrm{kg}$ and lethal dose $\left(\mathrm{LD}_{100}\right)$ was $2000 \mathrm{mg} / \mathrm{kg}$. Thus, when studying the toxicity of compound 4 , it was found that according to the current classification of the hazard of chemotherapeutic drugs according to the degree of effect on the body (GOST 12.1.00776), $\mathrm{N}$-( $\beta$-D-galactopyranosyl)-thiosemicarbazide belongs to substances III class of moderate hazard [13] [14]. That is why $\mathrm{N}-(\beta$-D-galactopyranosyl)thiosemicarbazide is a promising substance for its further study to use it in practice.

Table 1 shows comparison of antimycobacterial, antituberculosic, anti-viral (influenza), antineoplastic activity $(0.9>P a>0.5)$ and with a low probability of cytostatic/cytotoxic, antidiabetic activity properties for $\mathrm{N}-(\beta$-D-galactopyranosyl)thiosemicarbazide with the $\mathrm{N}$ - $(\beta$-D-xylopyranosyl)-thiosemicarbazide. Therefore, in addition to antibacterial activity, compound 4 possess high probability which can exhibit the above pharmacological properties, and is of interest as a promising drug for experimental studies.

\section{Conclusions}

An efficient method is proposed for the synthesis of carbohydrate derivatives of semicarbazides using the Lawesson reagent, which was not previously used for 
this class of compounds. The structures of the synthesized $\mathrm{N}$-( $\beta$-D-xylopyranosyl)thiosemicarbazide and $\mathrm{N}$-( $\beta$-D-galactopyranosyl)-thiosemicarbazide were established by physical research methods. The resulting substances are stable, individual compounds in crystalline form.

Based on in silico analysis of the results, $\mathrm{N}$-( $\beta$-D-galactopyranosyl)-thiosemicarbazide was selected from the two above-named compounds as the most promising antibacterial drug and with which experimental tests were carried out. The results of in vitro (antibacterial activity) and in vivo (toxic effects) experiments allow us to conclude that the theoretical prediction of the antibacterial activity of $\mathrm{N}$-( $\beta$-D-galactopyranosyl)-thiosemicarbazide confirmed by experimental data. Compound (4) in the studied concentrations has a pronounced bactericidal and bacteriostatic effect. It was also established that compound (4) belongs to the III class of hazardous substances; therefore, it can be concluded that $\mathrm{N}$-( $\beta$-D-galactopyranosyl)-thiosemicarbazide is a promising compound for further study to use it in practice.

\section{Conflicts of Interest}

The authors declare no conflicts of interest regarding the publication of this paper.

\section{References}

[1] Arora, S., Agarwal, S. and Singhal, S. (2014) Anticancer Activities of Thiosemicarbazides/Thiosemicarbazones: A Review. International Journal of Pharmacy and Pharmaceutical Sciences, 6, 34-41.

[2] Fossey, C., Landelle, H., Laduree, D. and Robba, M. (1994) Synthesis of N-1 $\beta$-DArabinofuranosyl and N-1-2'-Deoxy- $\beta$-D-erythro-pentofuranosyl Thieno [3,2- $d$ ] Pyrimidine Nucleosides. Nucleosides and Nucleotides, 13, 925-937. https://doi.org/10.1080/15257779408011866

[3] Cava, M.P. and Levinson, M.I. (1985) Thionation Reactions of Lawesson's Reagents. Tetrahedron, 41, 5061-5087. https://doi.org/10.1016/S0040-4020(01)96753-5

[4] Cherkasov, R.A., Kutyrev, G.A. and Pudovik, A.N. (1985) Tetrahedron Report Number 186: Organothiophosphorus Reagents in Organic Synthesis. Tetrahedron, 41, 2567-2624. https://doi.org/10.1016/S0040-4020(01)96363-X

[5] Ernazarova, B., Bakirova, A., Dzhumanazarova, A., Abdullaeva, Z., Berkmamatov, Sh. and Zhusupbaeva, G. (2020) Thionization Method of Glycosyl Urea and Carbamide Sugars. International Journal of Organic Chemistry, 10, 111-122. https://doi.org/10.4236/ijoc.2020.103008

[6] https://pharmaexpert.ru/PASSOnline/index.php

[7] Turner, R.A. (1967) Screening Methods of Pharmacology. Vol. 1, Academic Press, New York, London, 111-112. https://doi.org/10.1016/C2013-0-12513-5

[8] Barenboim, G.M. and Malenkov, A.G. (1986) Biological Active Substances. Science, Moscow, $284 \mathrm{p}$.

[9] Heyde, B.J., Glaeser, S.P., Bisping, L., Kirchberg, K., Ellinghaus, R., Siemens, J. and Mulder, I. (2020) Smectite Clay Minerals Reduce the Acute Toxicity of Quaternary Alkylammonium Compounds towards Potentially Pathogenic Bacterial Taxa Present in Manure and Soil. Scientific Reports, 10, Article No. 15397. 
https://doi.org/10.1038/s41598-020-71720-5

[10] Arzamastsev, E.V., Guskova, T.A., Lieberman, S.S., Lyubimov, B.I., Rudakov, A.G. and Verstakov, O.L. (1998) Guidelines for the Study of the General Toxic Effect of Pharmacological Agents. Pharmacological State Committee of the Ministry of Health, Russia, 27-32.

[11] Albert, A. (1987) Selective Toxicity. Part II, Medicine, Moscow, 49-56.

[12] Sanotsky, I.V. (1970) Methods for Determining the Toxicity and Hazard of Chemicals. Medicine, Moscow, 219-225.

[13] Sanotsky, I.V. and Ulanova, I.P. (1976) The Criterion of Harm in Hygiene and Toxicology in Assessing the Hazard of Chemical Compounds. Medicine, Moscow, 76-81.

[14] Litchfeild Jr., J.T. and Wilcoxon, F. (1949) A Simplified Method of Evaluating Dose-Effect Experiments. The Journal of Pharmacology and Experimental Therapeutics, 96, 99-113. 